\title{
ORGANIZATIONS' LIABILITY FOR TORTS OF VOLUNTEERS
}

\author{
JEFFREY D. KAHN $\dagger$
}

Volunteers are vital to our society. Diverse in their activities, volunteers donate their time and energy to such fields as social service, the arts, parks and recreation, health care, justice, religion, education, agriculture, and politics. Volunteers have always been an integral part of our society, ${ }^{1}$ but in recent years volunteering has become the subject of increasing public and political attention. As communities face the challenge of providing services and enhancing the quality of life in a time of reduced government spending, volunteers serve as an important resource. ${ }^{2}$

The growing influence of volunteerism ${ }^{3}$ raises a variety of important legal issues. ${ }^{4}$ This Comment will focus on the vicarious liability of organizations for injuries caused by their volunteers. According to the limited number of courts that have addressed this issue, organizations are liable for the torts of their volunteers to the same extent that they are liable for the torts of their salaried employees. ${ }^{5}$ Although this position is particularly burdensome to organizations that do not have close control over their volunteers, ${ }^{8}$ the imposition of liability is justified because the tort system can properly encourage organizations to develop better volunteer management practices. Undermining this encourage-

† B.A. 1983, Cornell University; J.D. Candidate 1986, University of Pennsylvania. The author wrote this piece while a student at the University of Pennsylvania Law School.

1 See generally S. Ellis \& K. Noyes, By the People: A History of AMeriCANS AS VOLUNTEERS (1978).

See, e.g., Karn, Volunteerism and the Budget Cuts, Volunterr VA., Fall 1981, at 1; Schindler-Rainman, Trends and Changesin the Volunteer World, in Voluntarism andSocialWork Practice, A Growing Collaboration, at xxx (F. Schwartz ed. 1984).

3 The word "volunteerism" has been coined to refer to the body of work performed by all types of volunteers in all settings. See S. ELLIS \& K. NoYeS, supra note 1 , at 11. Writers on volunteerism now recognize the existence of basic traits shared by all volunteer programs and a generic set of management tools that have proven to be successful in managing these programs. See id. at 264-67.

- See Younger Lawyers Section of the State Bar of Georgia, Legal Rights and Obligations of Volunterers and Volunteer Agencies (n.d.); Kahn, Legal Issues in Volunteerism: Preliminary Survey Results, J. VoluNTEER AD., Winter 1984-1985, at 31, 36.

- See infra text accompanying notes 29-63.

- See infra text accompanying notes 64-70. 
ment, however, is the insurance industry's practice of categorizing as high-risk those organizations that utilize volunteers. This policy ignores the differences among organizations in their level of control over volunteers, prevents the law from reaching its full potential in encouraging effective volunteer management, and erects a barrier against maximum volunteer participation. ${ }^{7}$ The Comment concludes by proposing a scheme that will help insurers more accurately assess the risks of volunteer participation and will assist organizations in developing the degree of control over their volunteers that the law presumes to exist. ${ }^{8}$

\section{Definitions and Scope of the Problem}

For purposes of this Comment, "volunteer" will be used to refer to someone who, of her own free will, "choose[s] to act in recognition of a need, with an attitude of social responsibility and without concern for monetary profit, going beyond what is necessary for one's physical well-being." The number of Americans who participate in volunteer activities is staggering. An estimated fifty-five percent of all American adults engage in volunteer activity. ${ }^{10}$ The value of time donated by volunteers in one year was estimated at approximately $\$ 64.5$ billion. ${ }^{11}$

7 See infra text accompanying notes 74-80.

See infra text accompanying notes 96-106.

- S. Ellis \& K. NoYEs, supra note 1 , at 10. This definition departs from some legal uses of the term "volunteer." See Black's LAw Dictionary 1413-14 (5th ed. 1979) (describing a volunteer as one giving services without promise of remuneration or one intruding into matters that do not concern her); Christenson, The Legal Definition of a "Volunteer," Voluntary ACTION LEADERSHIP, Fall 1982, at 17-18 (distinguishing between a "pure volunteer"-one who assists in work in which she has no interest and from which she expects no reward-and a "gratuitous employee"-one who serves on an ongoing basis without pay). "Volunteer" is also the legal label often given to a person who assists in a medical emergency. See Mapel \& Weigel, Good Samaritan Laws-Who Needs Them?: The Current State of Good Samaritan Protection in the United States, 21 S. TEx. L.J. 327, 330-43 (1980); Comment, Good Samaritan Laws-The Legal Placebo: A Current Analysis, 17 AKron L. Rev. 303, 304-05, 308-10 (1983).

${ }_{10}$ The 1983 Gallup Survey on Volunteering, reprinted in Allen, Volunteering in America: A Status Report, VolunTARY ACTION LEADERSHIP, Winter 1984, at 16, 20.

11 See Dollar Value of Volunteer Time, Voluntary ACTION LEaDERSHIP, Spring 1982, at 33, 33 (dollar value of contributed time for the year 1980, based on calculations done by the Independent Sector, a national consortium of corporations and nonprofit organizations concerned with volunteering and philanthropy).

This calculation, based on the average salary level of persons in the salaried workforce of the same age, sex, and education level as the average volunteer, may seriously underestimate the total value of volunteer time. See Karn, Money Talks: A Guide to Establishing the True Dollar Value of Volunteer Time (pt. 2), J. VolunTEER AD., Spring 1983, at 1, 2-7 (explaining that volunteer production is often underestimated because the number of volunteer hours is miscalculated); Karn, Addendum to "Money Talks," J. VolunTEER AD., Fall 1984, at 12, 12 (noting that volunteers do not receive the fringe benefits given to salaried workers and that most estimates of the dollar value 
Although volunteers work in the public sector, the for-profit sector, and the nonprofit sector, this Comment will focus on the nonprofit sector, in which the majority of volunteers are located..$^{12}$ In addition, this Comment will examine only the vicarious liability of organizations that can be sued as separate legal entities for the torts of their volunteers. ${ }^{19}$ Even with these qualifications, the analysis still covers tens of millions of Americans who volunteer and may be creating liability every day for the organizations for which they work.

The enormous size of the volunteer workforce indicates its huge contribution to society. The activities of volunteers benefit our communities, the organizations for which they work, and the volunteers themselves. Of course, a principal benefit of volunteers is economic. Volunteers allow an organization to do more with a limited budget than it could do if it had to pay all of its workers. The presence of volunteers also enhances an organization's ability to raise funds. ${ }^{14}$

Volunteering furthers and enhances the functioning of our democratic system and the values on which that system is based. Democracy

of volunteer time are therefore too low).

12 See Gallup Organization, Inc., Americans Volunteer 1981, at 3-5 (June 1981). The number of volunteers who work in the for-profit sector is rather small and includes mainly volunteers in for-profit hospitals and other health care facilities, student interns, and lawyers, accountants, and other professionals working as parttime pro bono publico consultants with small and minority-owned businesses. See $i d$.

The volunteer workforce in the public sector is very large and includes all of the volunteers in schools, courts, and local governments. See id. at 3-5. However, the issue of vicarious liability of units of government for torts committed by volunteers is considerably complicated by the issue of governmental immunity, which is beyond the scope of this Comment. See Greenhill, Recent Developments in Governmental and Charitable Immunities, 21 FED. INS. Couns. 123, 125-29 (1981).

13 According to a 1981 Gallup survey, five percent of American adult volunteers and six percent of American teenage volunteers work only informally or alone. See Gallup ORganization, INC., supra note 12, at 5. Even though these volunteers do not work for a particular formal organization, they are still volunteers and may have individuals as masters for purposes of vicarious liability. See, e.g., Heims v. Hanke, 5 Wis. 2d 465, 468, 93 N.W.2d 455, 458 (1958) (holding an uncle liable as master for nephew's tortious act committed while nephew was voluntarily helping wash uncle's car), overruled on other grounds, Butzow v. Wausau Memorial Hosp., 51 Wis. 2d 281, 187 N.W.2d 349 (1971).

This Comment also will not examine the liability of members of unincorporated associations for the torts of their nonmember agents. The imposition of vicarious liability in this context presents a unique set of problems. See Annot., 62 A.L.R.3D 1165 (1975).

14 A perpetual problem in the nonprofit sector is a shortage of funds. Organizations have been more successful raising funds when volunteers, rather than employees, are used to solicit money. See Letter from Susan Ellis, President of Energize Associates (consulting firm specializing in volunteerism) to Michele Silverman (Apr. 15, 1985) [on file with the University of Pennsylvania Law Review]. Furthermore, volunteer time may be included in an organization's contributions to matching grants, thereby increasing the amount to be contributed by the outside funding source. See id. 
is strengthened by the voluntary participation of citizens in all aspects of their communities. Through volunteering, citizens can effect change in society, gain a sense of control over their environments, and work together to improve their own lives. ${ }^{15}$

Volunteering "also makes a significant contribution to the volunteer's own psychological health and self-actualization."16 Volunteers themselves benefit from the services they donate by developing new skills, meeting new people, and having fun. ${ }^{17}$ Writers on volunteerism now recognize that the best volunteer activities benefit the givers of the service as much as the recipients. ${ }^{18}$

These benefits make the encouragement of volunteerism an essential policy goal. Nevertheless, a recent survey of directors of volunteers indicates that organizations' fears of incurring liability and concerns about high insurance rates may restrict the types of assignments that volunteers are given. ${ }^{18}$ Recent developments in the law relating to nonprofit organizations have heightened these concerns.

\section{Liability OF NoNPRofit ORganizations}

\section{A. The End of Charitable Immunity}

Until recently, most organizations that utilized volunteers were immune from all tort liability under the doctrine of charitable immunity. ${ }^{20}$ This form of immunity typically applied to organizations "cre-

16 See E. Schindler-Rainman \& R. LippitT, The Volunteer Community: Creative Use of Human Resources 15-19 (2d ed. 1977).

${ }^{16} I d$. at 15.

17 See K. Allen, S. McCurley \& D. Mosel, Will Volunteering Survive? 6-12 (1981).

${ }_{18}$ See, e.g., Allen, Volunteering in America in 1984: A Status Report, VolunTARY ACTION LEADERSHIP, Winter 1984, at 16, 17 ("We now recognize that volunteering is a mutually beneficial act, helping the helper as well as the consumer.").

19 See Kahn, supra note 4, at 33-36. The directors of volunteers from a variety of program settings indicated that legal issues substantially influenced program planning. See id. at 33. Of the respondents who said they had consulted with someone regarding a legal matter, the vast majority had sought information on liability or insurance. See $i d$. at 34-35. In addition, when asked what legal issues relating to volunteerism they would like more information about, the overwhelming majority of respondents mentioned liability. See id. at 36.

Further evidence of the importance of liability issues comes from the various state government agencies charged with promoting volunteerism within the states. Many of these agencies have felt the need to publish material about liabilities for the use of agencies in their states. See, e.g., Minnesota Office of Volunteer Services, DePARTMENT OF ADMinistration, InSURANCE COVERAGE FOR VOLUNTEERS (1984); Virginia Division of Volunteerism, Legal Liability in Volunteer Programs (n.d.) [manuscript on file with the University of Pennsylvania Law Review].

${ }_{20}$ See Annot., 25 A.L.R.4TH 517, 523-24 (1983). One of the few remaining states with charitable immunity is Arkansas. See J.W. Resort Inc. v. First Am. Nat'l Bank, 
ated and maintained exclusively as . . charit[ies]."21 Today there is a clear trend toward the abolition of such immunity and toward holding charitable organizations liable for the torts of their servants. ${ }^{22}$

According to one commentator, the most prevalent rationale for the abolition of charitable immunity has been that charitable organizations have control over the activities of their employees and agents and therefore are able to take precautions against injuries caused by them. ${ }^{23}$ As will be explored below, such control often does not exist over the acts of volunteers. ${ }^{24}$ Among the other arguments for abrogating charitable immunity are the increased solvency of many charitable organizations, ${ }^{25}$ the desire to provide an incentive for safe operations, ${ }^{28}$ and the increased availability of affordable liability insurance. ${ }^{27}$ In abolishing charitable immunity, however, courts and legislatures did not foresee the insurance industry's resistance to insuring organizations for the torts of their volunteers. ${ }^{28}$

As a consequence of the abolition of charitable immunity, tort victims are no longer forced to bear the cost of injuries caused by charitable organizations and their workers. Instead, the organizations themselves have been deemed responsible for, and capable of, absorbing this cost, and courts apply traditional tort doctrines to assess liability.

3 Ark. App. 290, 292, 625 S.W.2d 557, 558 (1981).

${ }^{21}$ J.W. Resort Inc. v. First Am. Nat'l Bank, 3 Ark. App. 290, 292, 625 S.W.2d 557, 558 (1981) (emphasis omitted).

${ }^{22}$ See Annot., supra note 20, at 547-51; see also Note, Charitable Immunity-An Anomaly of Tort Liability, 4 N.C. CENT. L.J. 133 (1972) (discussing the doctrine of charitable immunity as an exception to general principles of tort liability).

Charitable immunity has generally been eliminated through judicial action, see, e.g., Sullivan v. First Presbyterian Church, 260 Iowa 1373, 1380, 152 N.W.2d 628, 633 (1967); Albritton v. Neighborhood Centers Assoc. for Child Dev., 12 Ohio St. 3d 210, 214, 466 N.E.2d 867, 871 (1984); Nolan v. Tifereth Israel Synagogue, $425 \mathrm{~Pa}$. 106, 109, 227 A.2d 675, 675-76 (1967), but on at least one occasion has been eliminated through legislative action, see CAL. Crv. CoDE $\S 1714$ (West 1985).

${ }^{23}$ See Greenhill, supra note 12 , at 135 . This writer goes on to say that vicarious liability of charitable organizations "is of questionable application when the action is based on the negligence of pure volunteers-people who are not employees, and over whom the charity really has no control or right of control." Id.

24 See infra notes 64-70 and accompanying text.

${ }^{23}$ See Comment, Patient Recovery-A Poor Prognosis for Hospitals? The Expanding Scope of Hospital Liability, 10 OHIO N.U.L. REV. 519, 524 (1983).

${ }^{20}$ See id.

${ }^{27}$ See, e.g., President of Georgetown College v. Hughes, 130 F.2d 810, 824 (D.C. Gir. 1942); see also Keeton, The Impact on Insurance of Trends in Tort Law, in 1 Issues IN INSURANCE 70 (J. Long ed. 1981) (arguing that charitable organizations can prevent devastating tort judgments by procuring liability insurance at reasonable premium charges).

${ }^{28}$ See infra text accompanying notes 74-80. 


\section{B. Respondeat Superior}

When faced with a suit against an organization for an alleged injury caused by a volunteer, courts in jurisdictions without charitable immunity have applied the traditional doctrine of respondeat superior. ${ }^{29}$ There are currently only about a dozen reported cases addressing this issue, ${ }^{30}$ but the demise of charitable immunity and the increasing significance of volunteerism are sure to make these suits more common. Respondeat superior dictates that the master is liable for torts committed by the servant, ${ }^{31}$ regardless of the fault of the master. ${ }^{32}$ In order for respondeat superior to be imposed, three requirements must be met: (1) there must be an injury caused by the negligence or will of the servant; (2) there must be a master-servant relationship; and (3) the servant must have been acting within the scope of her employment. ${ }^{33}$

In order to make a discussion of the three requirements more concrete, this Comment will track the imposition of respondeat superior in one of the pioneering cases involving the liability of an organization for the torts of its volunteer, Baxter v. Morningside, Inc. ${ }^{34}$ In this case the volunteer performed errands for the charitable organization. The injury

29 See Scottsdale Jaycees v. Superior Court, 17 Ariz. App. 571, 499 P.2d 185 (1972) (volunteer caused accident on way to organization meeting); Sokolow v. City of Hope, 41 Cal. 2d 668, 262 P.2d 841 (1953) (volunteer for hospital auxiliary caused injury at fundraising fair); Malloy v. Fong, 37 Cal. 2d 356, 231 P.2d 241 (1951) (volunteer divinity student caused auto accident); Leno v. YMCA, $17 \mathrm{Cal}$. App. 3d 651, $95 \mathrm{Cal}$. Rptr. 96 (1971) (volunteer scuba instructor's negligent supervision led to student drowning); Vind v. Asamblea Apostolica de la Fe en Christo Jesus, $148 \mathrm{Cal}$. App. 2d 597, 307 P.2d 85 (1957) (volunteer minister in auto accident on way to meeting); Trinity Lutheran Church v. Miller, 451 N.E.2d 1099 (Ind. Ct. App. 1983) (volunteer driving to deliver holiday gifts injured motorcycle driver); Garcia v. Herald Tribune Fresh Air Fund, 51 A.D.2d 897, 380 N.Y.S.2d 676 (1976) (child staying with volunteer host family drowned in pool); Davis v. Shelton, 33 A.D.2d 707, 304 N.Y.S.2d 722 (1969) (local boy scout council held not liable for scoutmaster's alleged failure to supervise properly a boy scout who fell out of tree), appeal dismissed, 26 N.Y.2d 829, 257 N.E.2d 902, 309 N.Y.S.2d 358 (1970); Ricker v. Boy Scouts of Am., 8 A.D.2d 565, 183 N.Y.S.2d 484 (1959) (scoutmaster caused injury hanging flag at scouting event); Baxter v. Morningside, Inc., 10 Wash. App. 893, 521 P.2d 946 (1974) (volunteer driver for charitable organization caused injury); Manor v. Hanson, 120 Wis. 2d 582, 356 N.W.2d 925 (Ct. App. 1984) (volunteer driver for senior citizen transportation program caused accident); see also Annot., 82 A.L.R.3D 1213, 1219-23 (1978) (collecting cases).

${ }_{30}$ See cases cited supra note 29.

31 See Restatement (SECOND) of AgEncy \& 219 (1957).

32 See W. Keeton, D. Dobbs, R. Keeton \& D. OWen, Prosser and Keeton ON THE LAW OF TORTS 501-02 (5th ed. 1984) [hereinafter cited as Prosser].

ss See Restatement (SeCOND) OF Agency $§ 219$ (1957); see also Note, Vicarious Liability-A Limited Application of Respondeat Superior to Political Campaigning, 29 CASE W. RES. L. REv. 856, 871-72 (1979) (arguing for some application of respondeat superior to cases of volunteer campaign workers).

st 10 Wash. App. 893, 521 P.2d 946 (1974). 
in question was caused by a car accident that occurred while the volunteer was on an errand. ${ }^{35}$ The injured party sued both the volunteer, for his negligence, and the charity, under the doctrine of respondeat superior. The trial court dismissed the charity as a defendant, finding no vicarious liability as a matter of law. ${ }^{38} \mathrm{On}$ appeal, the court found that it was indeed possible for the charitable organization to be liable under respondeat superior doctrine. ${ }^{37}$ Since all of the requirements of the doctrine were satisfied, liability was imposed. ${ }^{38}$

\section{Negligence of the Servant}

Before any questions of organizational liability can be addressed, there first must be a finding that the servant was negligent. This element of respondeat superior operates independently of any examination of the relation between the volunteer and the organization and thus does not implicate the more complex problems of adapting the doctrine to cases of volunteers. ${ }^{3 \theta}$ In Baxter, for example, the trial court made a finding of fact that the volunteer driver negligently caused the accident, and the appellate court did not disturb this finding. ${ }^{40}$

At times, however, it may be difficult to define negligence in the case of a volunteer. Negligence is generally considered a departure from the required standard of care. ${ }^{41}$ This standard is grounded in the notion of expectations; one is expected to act as a reasonable person would act under the same circumstances. ${ }^{42}$ People may, however, have lower expectations of volunteers than of salaried workers, especially when vol-

ss See id. at 895,521 P.2d at 947-48.

se See id. at 894,521 P.2d at 947.

37 See id. at 899,521 P.2d at $949-50$.

38 See id. at 899,521 P.2d at 950.

so Negligence by volunteers may, however, provide unique problems of proof of injury and damages. Many volunteers work in situations in which intangible, and thus difficult to prove, injuries are likely to occur. The cases to date applying the doctrine of respondeat superior to the torts of volunteers have involved substantial physical injuries or death. See cases cited supra note 29. These cases presented no new problems of proving injury or causation; the pivotal issue was whether the organization could be liable for the torts of a volunteer. However, tort cases alleging other, less tangible injuries are now being successfully litigated. See, e.g., Molien v. Kaiser Found. Hosps., 27 Cal. 3d 916, 616 P.2d 813, 167 Cal. Rptr. 831 (1980) (recognizing cause of action for negligent infliction of emotional distress); Portee v. Jaffee, 84 N.J. 88, 417 A.2d 521 (1980) (same). The work of many volunteers revolves around interpersonal relationships, providing support for others in times of trouble or vulnerability and other situations in which emotional injuries may be caused by negligent volunteers. The absence of suits involving intangible injuries may reflect the difficult problems of proof in such suits or perhaps the novelty of the legal remedy.

10 See 10 Wash. App. at 899,521 P.2d at 949-50.

42 See Prosser, supra note 32, at 164.

42 See id. at 173-93. 
unteers are filling roles also held by salaried workers. If volunteers are perceived to be less skilled than salaried workers, this perception may produce lower expectations of ability, and the courts may require a lower standard of care for volunteers.

\section{Master-Servant Relationship}

For those courts that have dealt with respondeat superior doctrine in cases of alleged injuries by volunteers, finding a master-servant relationship has been the most troublesome part of the analysis. Before a relationship will be designated as master-servant, the common law mandates that three conditions must be satisfied: (1) the master must have the right to control the physical conduct of the servant; (2) the master must consent to the receipt of the service; and (3) the master must expect to receive some benefit from the service. ${ }^{43}$

The right-to-control requirement raises difficult questions in cases involving volunteers. It is not immediately obvious that organizations have as much right to control their volunteers as employers have to control their salaried employees. Nevertheless, most cases have concluded that the right to control exists in a volunteer-organization relationship. ${ }^{44}$ The common law does not require the actual exercise of this right but merely its presence. ${ }^{45}$ The payment of a salary is not necessary to establish the right to control, ${ }^{46}$ and even though volunteers can

is See Note, supra note 33, at 870-72; see also Restatement (Second) of AGENCY $\S 2$ (1957) (defining master and servant); id. § 221 (requiring consent).

14 See, e.g., Trinity Lutheran Church v. Miller, 451 N.E.2d 1099 (Ind. Ct. App. 1983); Baxter v. Morningside, Inc., 10 Wash. App. 893, 521 P.2d 946 (1974). But see Davis v. Shelton, 33 A.D.2d 707, 304 N.Y.S.2d 722 (1969) (right of control did not exist between boy scout council and volunteer scoutmaster), appeal dismissed, 26 N.Y.2d 829, 257 N.E.2d 902, 309 N.Y.S.2d 358 (1970).

13 See, e.g., Marvel v. United States, 719 F.2d 1507, 1514 (10th Cir. 1983); Coleman v. Board of Educ., $477 \mathrm{~Pa}$. 414, 421-22, 383 A.2d 1275, 1279 (1978).

16 The Restatement (Second) of Agency states that "[o]ne who volunteers services without an agreement for or expectation of reward may be a servant of the one accepting such services.” Restatement (SECOND) OF AGENCY § 225 (1957). This statement has been relied on extensively by courts in finding a master-servant relationship when there is no salary or other payment to the servant. See, e.g., Duffy v. Harden, 179 N.W.2d 496, 503 (Iowa 1970); Mansfield v. Smithie, 615 S.W.2d 649, 653 (Mo. Ct. App. 1981); Jones v. Herr, 39 Or. App. 937, 941, 594 P.2d 410, 412 (1979). But cf. Crum v. Walker, 241 Iowa 1173, 1178, 44 N.W.2d 701, 704 (1950) (Even though there does not have to be payment of wages, there must be some "lawful consideration for the contract of employment" to establish the master-servant relationship.).

The cases and the examples given in the comments to section 225 of the Restatement, however, do not involve volunteers as the term is being used in this Comment. Rather, the comments and illustrations focus on gratuitous servants who do a favor for an individual, often someone they know, receive no compensation, and serve for only one particular occasion. See Restatement (SECOND) of AGENCY $\S 225$ comments a, b, illustrations 1,3 (1957). 
be fired, ${ }^{47}$ the possibility of termination is not, as with salaried employees, the primary evidence of the right to control. ${ }^{48}$ Rather, courts have looked to the presence of specific instructions given to volunteers and the nature of the agreement between the volunteer and the organization to determine whether the requirement of control is satisfied. ${ }^{49}$ For example, in Baxter the court noted that the volunteer and organization specifically agreed on the purpose, destination, and details of the volunteer's task. ${ }^{\text {so }}$ Direct supervision of the volunteer was not necessary to establish the right to control. ${ }^{.1}$

Courts will at times consider how an organization represents its relationship with a volunteer to the public in determining the existence of the right to control. ${ }^{52}$ The conduct of the volunteer and the organization after the tort in question has taken place may also evidence control. For example, in Garcia v. Herald Tribune Fresh Air Fund, ${ }^{\text {s3 }}$ an organization told its volunteer that it would handle all legal matters re-

47 See Park, The Fourth R: A Case for Releasing Volunteers, J. VolunTeER AD., Spring 1984, at 1, 7; Should Volunteers Be Fired? Several Considerations, VoLUNTARY ACTION LEADERSHIP, Fall 1979, at 27, 29.

48 In the case of salaried employees, courts generally assume that the employer's power to fire the worker operates to establish the right to control, even if no such threat is actually made. See Note, supra note 33 , at 871.

48 See, e.g., Trinity Lutheran Church v. Miller, 451 N.E.2d 1099, 1102-03 (Ind. Ct. App. 1983) (when an organization directs the way in which a volunteer performs a task, even if the volunteer does not assent, the right to control may be established by the volunteer actually following the proferred instructions); Manor v. Hanson, 120 Wis. 2d 582, 585-86, 356 N.W.2d 925, 926-27 (Ct. App. 1984) (explicit written agreement of the volunteer to abide by the organization's instructions in performing the task established the right to control). Direct supervision of the volunteer is not necessary to establish the right to control. Cf. Manor, 120 Wis. 2d at 585, 356 N.W.2d at 926 (organization found to be master of volunteer driver even though it had never met with the driver after the initial orientation and had no control over the volunteer's schedule).

so See 10 Wash. App. at 898, 521 P.2d at 949.

${ }^{51}$ See id.

32 See, e.g., Leno v. YMCA, 17 Cal. App. 3d 651, 658, 95 Cal. Rptr. 96, 100 (1971). The issue of how an organization presents to the public its relation to its volunteers was also emphasized by the Supreme Court in American Soc'y of Mechanical Eng'rs v. Hydrolevel Corp., 456 U.S. 556 (1982). Although this case involved an antitrust action against a professional society composed of volunteer members (and thus falls outside the scope of this Comment), it is worth noting because it is the only time that the Supreme Court has held that an organization may be liable for acts committed by its volunteers. In holding the organization liable under the antitrust laws for the acts of these volunteers, the Court relied primarily on the doctrine of apparent authority. See id. at 566. Significant to the analysis in this Comment is the Court's note that the association was in the best position to prevent these volunteers from violating the law. See id. at 576.

For further commentary on Hydrolevel, see Curran, Volunteers ... Not Profiteers: The Hydrolevel Myth, 33 CATH. U.L. REv. 147 (1983); Case Comment, Nonprofit Associations are Subject to Antitrust Liability for the Acts of Their Agents with Apparent Authority, 60 WASH. U.L.Q. 1487 (1983).

${ }^{83} 51$ A.D.2d 897, 380 N.Y.S.2d 676 (1976). 
garding her accident. The court considered this conduct evidence of the master-servant relationship. ${ }^{\text {s4 }}$

The requirement of consent poses few difficulties in applying respondeat superior to organization-volunteer relationships. As with the right to control, the consent of the master need not be explicit in order for the relationship to be found to exist. ${ }^{.55}$ In Baxter the organization specifically requested that the volunteer perform the errand, and thus consent was evident. ${ }^{56}$ Often, notations about the volunteer in an organization's records or the formalized nature of the volunteer program indicate implicit consent. ${ }^{.57}$

Finally, the requirement that the master behefit from the volunteer's work is easily satisfied. ${ }^{58}$ The court in Baxter determined that the volunteer was benefiting the organization by doing the errand. ${ }^{59}$ By fulfilling a need of the organization, the volunteer's work benefits the organization.

The common law, with its immunity for charitable organizations, most likely did not envision the application of the doctrine of respondeat superior to cases involving volunteers. Nevertheless, all three elements of the master-servant relationship are generally found to exist in cases of volunteers working for organizations.

\section{Scope of Employment}

Once it is established that the volunteer has caused an injury and that the volunteer was a servant of the organization, liability will be imposed on the organization only if it is determined that the volunteer was acting within the scope of her "employment" at the time of the injury. ${ }^{60}$ The tests for scope of employment are varied and

84 See id. at $897-98,380$ N.Y.S.2d at 679.

ss See, e.g., Scottsdale Jaycees v. Superior Court, 17 Ariz. App. 571, 574, 499 P.2d 185, 188 (1972) ("IT]here is no dispute that the Scottsdale Jaycees consented to [the alleged injurer] acting as a volunteer . . . and hence he can be considered a servant or agent in the realm of respondeat superior . . . .").

${ }^{68}$ See 10 Wash. App. at 897-98, 521 P.2d at 949; see also Burns v. Sams, 458 So. 2d 359, 360 (Fla. Dist. Ct. App. 1984) ("A person who voluntarily assists in the work of another with his consent may become a servant of the latter and that consent need not be expressed, but may be implied."); $c f$. Galvan v. Peters, 22 Wis. 2d 598, 126 N.W.2d 590 (1964) (since the ride was not arranged by a church official, a person involved in an automobile accident while voluntarily driving church members home from church held not a servant of the church).

${ }^{67}$ See Baxter at 897-98, 521 P.2d at 949.

s8 See, e.g., Scottsdale Jaycees v. Superior Court, 17 Ariz. App. 571, 499 P.2d 185 (1972).

so See 10 Wash. App. at 896, 521 P.2d at 949.

oo See Restatement (Second) of Agency § 219 (1957) (explaining when master is liable for torts of servant). 
complex. ${ }^{61}$ One commentator, summarizing the tests, states that the emphasis is on how others perceive the relation: "[T] is a servant when, in the eyes of the community, he would be regarded as a part of the employer's own working staff, and not otherwise." ${ }^{\text {2 }}$ In cases involving volunteers, courts' inquiries follow lines similar to those followed in cases involving salaried workers. In Baxter the court noted that the service performed was precisely that directed by the organization and thus was within the scope of employment. ${ }^{63}$

\section{RESPONDEAT SUPERIOR AND THE INSURANCE INDUSTRY IN CONFLICT}

\section{A. The Effect of Tort Liability on Organizations}

The message of the application of respondeat superior doctrine to the torts of volunteers is that organizations must find ways of properly controlling the behavior of volunteers in order to reduce the chances of tort liability ${ }^{64}$ The courts have almost always found the requisite right to control, yet, in fact, most organizations have less control over volunteers than they have over salaried employees.

Volunteers present different challenges to an organization attempting to exercise control than do salaried employees. Even though volun-

-1 See Note, supra note 33, at 872-76; Restatement (SeCOND) of Agency § 228 (1957) (general statement on scope of employment).

62 See Prosser, supra note 32, at 501.

6s 10 Wash. App. at 896-98, 521 P.2d at 948-49. Compare Scottsdale Jaycees v. Superior Court, 17 Ariz. App. 571, 499 P.2d 185 (1972) (holding that volunteer was not acting within the scope of his employment while he was traveling to an organization meeting as a designated delegate) with Vind v. Asamblea Apostolica de la Fe en Christo Jesus, 148 Cal. App. 2d 597, 307 P.2d 85 (1957) (facts similar to Scottsdale, but volunteer found to be within scope of employment).

of One possible effect of applying the doctrine of respondeat superior is that the organization will deliberately structure the volunteer-organization relationship loosely so that the necessary nexus of control will be found lacking. The organization can thus disavow responsibility for volunteers' torts and be free from liability while benefiting from the volunteers' services. For example, one commentator found that the relationship between New York Gity and the Guardian Angels (youth volunteers who patrol subways to promote safety and prevent crime) achieved this end. The agreement between them gave the city no say in selecting members or in scheduling the volunteers. Although the agreement did provide for the city to receive regular information on the volunteers' activities, the author nonetheless concluded that the control needed to establish a master-servant relationship was absent. See Comment, Municipal Liability for Torts Committed by Volunteer Anticrime Groups, 10 FordHAM URB. L.J. 595, 62728 (1982).

Nevertheless, in most situations it is disadvantageous for an organization to create an appearance of no control over the volunteer since courts almost always find that the necessary control exists anyway. As stated above, the courts look to the right to control, not the actual control exercised. See supra notes 44-54 and accompanying text. 
teers have a substantial stake in their positions, ${ }^{65}$ the threat of termination is obviously less powerful for volunteers than than it is for salaried workers. Thus, in the case of volunteers, organizations lack one of the most important means of assuring compliance with organizational policies.

Furthermore, the way an organization perceives its volunteers will affect its willingness to exercise control. Many organizations have low expectations of performance for their volunteers, fearing that if they try to impose higher standards or exercise significant control, they will discourage potential volunteers. ${ }^{68}$ This phenomenon may be called the "gratitude factor": when an organization hires an employee, the organization realizes that the employee receives financial gain from the relationship, and it therefore feels justified in demanding a certain level of performance from the employee. When an organization gains assistance from a volunteer, however, the organization may be so grateful for any help that it is reluctant to make demands on the volunteer. ${ }^{67}$

Organizations also find volunteers difficult to control because of the types of tasks volunteers perform and the way that volunteer work is scheduled. Most volunteers serve only part-time ${ }^{68}$ and may not work on a regular schedule. In addition, much volunteer work is performed "in the field," outside of the organization's office. ${ }^{6 \theta}$ This large amount of offsite work means the contact between volunteer and supervisor is often less frequent and regular than that between salaried employee and supervisor. It is therefore more difficult for the organization to monitor and influence the behavior of a volunteer. ${ }^{70}$

${ }^{65}$ Many people volunteer to learn skills or to gain experience useful in the salaried workforce, as well as to satisfy feelings of altruism. See, e.g., Love, Getting as Much as You Give, SELF, Feb. 1982, at 14 (discussing the achievement of "professional points" as well as "personal satisfaction" from volunteering); C. Truesdell, Transferability of Volunteer Skills: How and Why (1980) (commentary distributed by Adelphi University's Center on Volunteerism) (discussing the fact that volunteers are increasingly asking their employers to recognize the skills gained from volunteer work); see also supra notes 16-18 and accompanying text.

${ }^{68}$ One writer, criticizing this common attitude, says that "it is widely assumed ... that, if a prospective volunteer shows up on an organization's doorstep, 'hiring' is a foregone conclusion." Park, supra note 47, at 3. The same writer discusses the importance of demanding accountability from both volunteers and salaried staff, but notes the reluctance of many groups to impose this on volunteers. See id. at 3-4.

${ }^{67}$ A variation of this phenomenon is the attitude of some organizations that volunteers' motives are suspect and that volunteers are somehow foolish for working without pay. When an organization doubts the motives and abilities of a volunteer, this becomes a self-fulfilling prophecy, and the volunteer tends not to perform at high levels.

${ }_{68}$ The 1983 Gallup Poll showed that $57 \%$ of working people also volunteer. The 1983 Gallup Survey on Volunteering, reprinted in Allen, supra note 10, at 21.

"Q Familiar examples include volunteer "friendly visitors," "big brothers" and "big sisters," and scouting troop leaders.

70 This is not to say that organizations do not keep track of volunteers' work. 
The combined effect of the reduced impact of the threat of termination, the gratitude factor, and volunteers' time schedules and offsite work makes it difficult for organizations to supervise volunteers. The growing sophistication in volunteer management, however, has enabled many organizations to surmount these difficulties and develop successful ways to oversee volunteers. These organizations recognize that time and effort devoted to training and supervising volunteers produce higher levels of volunteer performance. ${ }^{71}$ When organizations expect a certain level of performance from volunteers and establish standards of accountability, the attitude of the volunteers is affected. Rather than viewing the quality of their work as unimportant, volunteers feel responsible for their activities and take pride in their work. The result of this effort by management is that volunteers are more careful and thus less likely to perform negligently. Volunteers, as this latter group of organizations proves, are not inherently impossible to control, but a degree of imagination and energy is required to develop such control.

Since organizations assign volunteers to tasks in which the volunteers could injure third parties, it is reasonable to expect organizations to oversee the activities of their volunteers. If organizations are liable for injuries caused by volunteers, there is a strong economic incentive to take precautions in selecting and supervising them. ${ }^{72}$ Thus, imposing liability based on the doctrine of respondeat superior appropriately encourages organizations to develop control over their volunteers. ${ }^{73}$ The

Many volunteer programs keep careful records of the hours volunteers work and the tasks they perform. See generally S. Ellis \& K. Noyes, ProOf Posittve: Developing Significant Volunteer Recordkeeping Systems (1980) (Volunteer Energy Series) (suggesting ways to design and maintain records for volunteer programs).

71 For example, the evaluation of volunteers' performance is an integral part of many volunteer programs and is recommended by experts in volunteer management. See, e.g., K. Brown, Keys to Making a Volunteer Program Work 67-78 (1982).

72 See Prosser, supra note 32, at 501.

73 There are some situations in which the master cannot, despite the economic incentives, monitor and influence the servant's actions to reduce risk. For example, suppose that a volunteer working for a church visits sick people in their homes and brings them food packages. The church tells her which people have expressed a desire to have such visitors, and the church provides her with the packages. However, she schedules the visits herself and uses her own discretion to govern her conduct while in the clients' homes. A volunteer performing this type of service was held to be a servant of the church in Trinity Lutheran Church v. Miller, 451 N.E.2d 1099 (Ind. Ct. App. 1983). The church was held liable for an automobile accident caused by the volunteer. See id. at 1101.

Suppose the volunteer, while visiting someone's home, negligently knocks over a valuable vase and breaks it. Should the church be held liable? Clearly, the volunteer was acting within the scope of her employment, and the principle of respondeat superior will be applied. Yet there was nothing the church could have done to prevent such damage. The application of respondeat superior here fails to serve its function of en- 
current insurance situation, however, precludes the effective use of this doctrine and may operate to discourage volunteerism.

\section{B. The Insurance Industry and Organizations with Volunteers}

In the eyes of commercial insurance underwriters, the presence of volunteers within an organization raises a "red flag." panies are reluctant to cover volunteers, believing that the organization does not control the volunteers, that volunteers are not effectively screened or trained, that volunteers may not be motivated to succeed in their assignments, and that volunteers are inadequately supervised. ${ }^{\mathbf{7 5}}$ As a result of these perceptions, volunteers are either excluded from many liability policies or are assigned to high-risk rate categories, and the organizations are charged correspondingly high premiums. ${ }^{76}$

This pattern in the insurance industry is at odds with the realities of volunteerism. The automatic assignment of organizations that utilize volunteers to high-risk categories ignores the fact that such organizations exercise different amounts of control over their volunteers. Insurers unrealistically consider the vast volunteer workforce to be homogeneous and assume that most organizations are inept in their management of volunteers.

This reaction of insurers stems largely from a lack of knowledge about volunteers and the nonprofit world. Although nonprofit organizations are often excellent insurance risks, ${ }^{77}$ insurers erroneously believe that these organizations are not profitable to insure. ${ }^{78}$ The presence of volunteers merely accentuates the impression of uncertainty and risk in

couraging precautions. See Note, An Efficiency Analysis of Vicarious Liability Under the Law of Agency, 91 YALE L.J. 168, 169, 190-91 (1981). In most cases, however, the organization can prevent damage by training its volunteers better. The benefits of imposing the respondeat superior doctrine to encourage such training in the majority of cases outweigh the doctrine's ineffectiveness in the rare case when an organization could not have prevented the harm.

74 See Chapman, Volunteer Insurance, Voluntary Action Leadership, Winter 1980 , at 23. 15.

${ }^{75}$ See Lynes, Yes-Insurance is Necessary, J. VolunTary AD., Spring 1979, at

76 See T. Chapman, M. Lal \& E. Steinbock, Am I Covered For . . . ?-A Guide to INSURANCE FOR NoN-Profits 115-16 (1984); Chapman, supra note 74, at 23; see also Lynes, supra note 75 , at 15.

77 Telephone interview with Rodney Harvey, Underwriting Manager, First Non Profit Pooling Trust (Feb. 11, 1985).

78 One organization that insures only nonprofit organizations reports a pure-loss ratio (incurred losses/premiums earned) of $63 \%$ over a five year period; the average pure-loss ratio for the insurance industry is between $75 \%$ and $80 \%$. Telephone interview with Rodney Harvey, Underwriting Manager, First Non Profit Pooling Trust (May 30, 1985). 
the minds of insurers. ${ }^{79}$ Without proper knowledge about volunteer programs, underwriters lack the proper criteria with which to evaluate the risks involved.

Although organizations that utilize volunteers react in various ways to the insurance situation, one can conclude safely that extremely expensive insurance tends to discourage an expansion of volunteers' roles. Many organizations limit the responsibilities of their volunteers to keep premiums down. ${ }^{80}$ Restrictions on volunteer activity conform to insurers' perceptions about what volunteers can do, but do not accurately reflect volunteers' capabilities.

The difficulty in obtaining affordable insurance also serves to undermine the incentive to carefully supervise and train volunteers created by the imposition of respondeat superior. Even if an organization institutes changes in its management of volunteers in response to the influences of the tort system, that organization may not realize the immediate reward of lower insurance rates. Flexible insurance rates that vary depending on the ability of an organization to control volunteers would provide an incentive to improve that control. The current rigidity in rate assignments counters the effect of respondeat superior in encouraging control.

\section{Solutions to the Insurance Problem}

The difficulty of obtaining affordable insurance to cover volunteers' torts has not gone unnoticed. One commentator has suggested three alternatives to address this problem: immunity for volunteers, risk pooling, and increased advocacy. ${ }^{81}$ Since none of these proposals meets the immediate needs of most organizations, however, this Comment proposes a fourth alternative, an insurance regulation. ${ }^{\mathbf{8 2}}$

The first suggested alternative is legislative exemption of volunteers and nonprofit organizations from tort liability. ${ }^{83}$ Although at least one state is now considering such legislation, ${ }^{84}$ such laws are unlikely to

70 See id.

${ }^{80}$ See Letter from Diane Pasta, Supervisor of Volunteers for Senior Rights Assistance, to Linda Crerar, State Center for Voluntary Action (Mar. 28, 1983) (noting that her organization structures volunteer roles so as to keep insurance premiums affordable) [on file with the University of Pennsylvania Law Review].

81 See Lynes, supra note 75, at 16.

82 See infra text accompanying notes 96-106.

8s See Lynes, supra note 75, at 16.

8t The Attorney General of Arkansas is preparing to introduce a statute to the state legislature that would "protect volunteers, volunteer organizations, and clients from liability. Under this law, volunteers would be required to have job descriptions, appropriate training and be registered as a volunteer with the organization (record keeping would be necessary)." Letter from Maralynn Troutmann, Program Developer, 
be widely adopted given the growing trend toward abolishing charitable immunity. ${ }^{85}$ In addition, immunity laws, unlike the doctrine of respondeat superior, provide no incentive for organizations to better supervise volunteers.

The second proposal suggests that, because insurance companies do not recognize the true diversity in volunteer management, organizations should form large groups, pool their resources, and become selfinsurers. ${ }^{88}$ Pursuant to legislation in Illinois, ${ }^{87}$ one such "pool" has been formed. ${ }^{88}$ Nonprofit, federally tax-exempt organizations pay premiums into a common fund from which claims are paid out. ${ }^{89}$ This pooling enables nonprofit organizations to circumvent the problems of obtaining commercial insurance. Because the pool's underwriters are familiar with nonprofit organizations and their reliance on volunteers, they can realistically assess the risk for potential insureds and provide the organizations with appropriate underwriting. ${ }^{90}$

Insurance rates that vary with the actual degree of risk encourage organizations to minimize their risk by improving volunteer management, thus reinforcing the goals of the doctrine of respondeat superior. Despite these advantages, however, there are significant barriers to the formation of insurance pools. Enabling legislation must be passed prior to their formation, and, to date, Illinois is the only state that has such laws. ${ }^{91}$ Efforts to enact similar legislation in other states have failed. ${ }^{\boldsymbol{2}}$ In addition, even if proper legislation were passed, it would be some time before the pools could be sufficiently organized to encompass all of the organizations that currently utilize volunteers. In the meantime, the expansion of volunteerism may be hampered by the lack of available insurance. Risk pooling remains an important and promising alternative, but a more immediate solution is needed.

The third suggested alternative involves advocacy by nonprofit organizations on a nationwide scale to "impact insurance companies and

Arkansas Office of Volunteerism, to Jeffrey Kahn (Jan. 11, 1985) [on file with the University of Pennsylvania Law Review].

8s See supra notes 20-28 and accompanying text.

${ }^{86}$ See Lynes, supra note 75, at 16.

87 Ill. ANN. STAT. ch. 148, §§ 201-227 (Smith-Hurd Supp. 1984).

ss See Georgandas, Insurance Coverage for Nonprofits, NONPROFIT WORLD REP., July-Aug. 1983, at 28.

${ }^{80}$ See $i d$. Recent data shows that some 714 nonprofit organizations are beneficiaries, and annual contributions earned are in excess of $\$ 2.3$ million. See Frrst

Trust: A Non Profit Risk Pooling Entity, 1984 Annual Report (1985).

so See telephone interview with Rodney Harvey, supra note 77.

91 ILl. ANN. Stat. ch. 148, §§ 201-227 (Smith-Hurd Supp. 1984).

${ }^{22}$ Attempts were made in California and Indiana. See telephone interview with Rodney Harvey, supra note 77. 
to negotiate rates." ${ }^{\text {"93 }}$ This proposal also fails to meet the current needs of organizations. One group that has attempted such advocacy reported that "the insurance industry as a whole revealed its unwillingness to engage in extended sessions of consistent, change-oriented dialogue."94 This group concluded that, "if major policy changes were to occur, they would do so without immediate and willing participation of the [insurance] industry."95 This experience suggests that advocacy will be ineffective in changing the insurance industry's policy in this area.

If insurers will not voluntarily recognize the differences among volunteer programs and the possibility of reducing risks through close supervision, a statutory requirement to do so may be necessary. Without such a requirement, the efficacy of the doctrine of respondeat superior to encourage better volunteer management is diluted, and volunteer participation may be discouraged. This Comment proposes a general statutory scheme ${ }^{\theta 8}$ that entitles organizations to preferential insurance treatment if they meet certain requirements in their volunteer management methods. The proposal recognizes that insurers lack the knowledge to differentiate properly among volunteer programs and forces insurers to make distinctions based on some rational and dependable criteria.

In order to qualify for favorable insurance treatment, organizations would be required to satisfy certain verifiable criteria. ${ }^{97}$ The core requirement of this Comment's proposal is the creation of a written job description for every volunteer in an organization's program. A written job description is a vital tool in the management of volunteers. ${ }^{98}$ Indeed, many established programs already utilize written job descriptions for every volunteer. ${ }^{89}$

os See Lynes, supra note 75, at 16.

24 Telephone interview with R. Eugene Lokey, Director of Governmental Relations for the Consortium for Human Services (Aug. 27, 1985).

${ }^{25} \mathrm{Id}$.

96 Note that the goal of this portion of the Comment is not to draft a particular statute but rather to provide general guidelines.

97 These requirements are similar to those envisioned by the Arkansas Attorney General's Office. See supra note 84 .

${ }^{\circ}$ See M. Wilson, The Effective Management of Volunteer Programs 101-20 (1976); Cauley, Job Descriptions: Matching Volunteer Skills with Agency Needs, Synergist, Winter 1974, at 36; Ellis \& Noyes, Citizens Inside: Supporting Teamwork, CORRECTIONS TODAY, June 1983, at 48.

9o See, e.g., American Assoc. Of Zoological Parks \& Aquariums, VolunTEers in Zoos and AQUARIUMS, at III-6 (1981); DeP'T of Social Servs., State of Utah, Job Descriptions for Volunteers in Utah Human Services (1983); Nat'l Park Serv., U.S. DeP'T OF the INTERIOR, Volunteers IN THE PaRks 29 (1982); UNIted Gerebral Palsy Ass'NS, INC., UCP's "Heart and ENERGY": A Volunteer Development Program for United Gerebral Palsy Affiliates 13 (1981); United Church of Christ, The Ministry of Volunteers: A Guide- 
Under this proposal, the job description must be fairly detailed and should include the volunteer's name and title, the program for which the volunteer works, a designated supervisor for the volunteer, a list of the volunteer's duties, a description of training and orientation received by the volunteer, ${ }^{100}$ and specification of the time commitment expected from the volunteer. In addition, the organization must keep records of when each volunteer works. ${ }^{101}$ Each volunteer must sign and date her job description form on the first day she works, verifying the existence and accuracy of the description. The document would thus predate any tort of the volunteer for which the organization might be liable under the doctrine of respondeat superior.

A detailed job description facilitates better volunteer management and thus minimizes risks. The exercise of writing out the volunteer's duties in order to receive preferential insurance rates encourages organizations to pinpoint the skills needed for each job and to recruit volunteers who have those skills. ${ }^{102}$ More qualified volunteers are less likely to cause injuries. The job description also forces the organization to anticipate which tasks are potentially dangerous, alerting the organization to the need for proper volunteer training and supervision for those tasks, ${ }^{103}$ and helping alert the volunteer of possible risks of personal liability. Additionally, the job description will serve as a yardstick for evaluating (and thus improving) volunteers' performances. ${ }^{104}$ Finally, the mandatory assignment of a specific supervisor designates responsibility to control the volunteer.

In order to make certain that insurers adjust their rates for organizations that comply with the statutory requirements, the enacting state could also establish a monitoring commission, composed of representatives from the nonprofit sector, the insurance industry, and the state. This commission would have the responsibility of ensuring that insurers are not discriminating unfairly against organizations utilizing volunteers and are appropriately distinguishing between qualifying and nonqualifying organizations. The commission could also make recom-

BOOK FOR CHURCHES 12 (1979).

100 "Training" is the teaching of specific skills needed to perform the job; "orientation" is the presentation of a general overview of the organization's purpose, facilities, staff, etc. See E. Schindler-RAINMAN \& R. LIPPITT, supra note 15, at 64-81.

101 See Ellis \& Noyes, supra note 98, at 64.

102 See Cauley, The Valuable, Vital Volunteer Job Description, VolunTaRY ACTION LEADERSHIP, Spring 1978, at 26.

${ }^{109}$ See, e.g., American National Red Gross, Volunteer Personnel AdMINistration HANDBOOK $\S I V$, at 2 (1984) (In order to minimize losses "it is essential that volunteers receive training, guidance, and direction as to how to do their duties without incurring liability.").

104 See Cauley, supra note 98, at 26. 
mendations to the legislature concerning the substance of the qualifications an organization must meet in order to obtain preferential treatment.

From the perspective of organizations, this proposal would give direction on how to structure volunteer management. Public promotion of the proven technique of written job descriptions, combined with the strong insurance incentive, would encourage organizations to use job descriptions. Organizations would find administering volunteer programs easier and, armed with both management tools and flexible insurance treatment, would be able to expand the roles of volunteers.

From the viewpoint of volunteers, the proposal would encourage the expansion of their roles. Furthermore, the job description would serve to clarify the goals of the job. A management system based on written job descriptions could aid volunteers in accomplishing their goals. Supervision, training, and evaluation of volunteer performance, all furthered by written job descriptions, are signs that the organization respects the volunteer, not that the organization distrusts the volunteer. By spending time and energy helping volunteers to function effectively, the organization would confer the most effective type of recognition possible. ${ }^{105}$

One possible objection to the increased supervision and control of volunteers is that it may undermine the value of volunteering by introducing an element of hierarchy into volunteer programs. The imposition of some structure is, however, necessary if groups are to function efficiently. ${ }^{108}$ Since individuals donate their time as volunteers specifically to accomplish tasks, a degree of structure and supervision would add to their experience, not detract from it.

From a legal perspective, the proposal would aid courts in applying the doctrine of respondeat superior in torts involving volunteers. By establishing the right to control and by defining the scope of employment, the proposal would facilitate judicial adoption of the traditionally employee-oriented doctrine.

Finally, from a social perspective, this proposal would encourage an expansion of volunteerism by facilitating the availability of affordable insurance. Moreover, the proposal would aid in reducing the incidence of negligence among volunteers by providing a strong incentive to develop management systems that encourage effective and safe volun-

103 See Friedlieb, Volunteer Recognition Is:, AdelPHI UNIVERSITY's CENTER ON VolUNTEERISM COMMENTARY, Oct. 1979, at 1.

${ }^{108}$ Cf. Joreen, The Tyranny of Structurelessness, in Radical FEмINISM 296-97 (A. Koedt, E. Levine \& A. Rapone eds. 1972) (discussing the impact of "structurelessness" on the women's liberation movement). 
teering. In meeting the inevitable opposition of the insurance lobby, legislators should realize that this system is not necessarily contrary to the interests of the insurance industry. Unlike risk-pooling legislation, this proposal does not create a separate insurance entity to compete with commercial insurance companies. Rather, it helps companies profitably insure volunteer programs by accurately assessing the risks. The adoption of the proposal would encourage organizations to buy proper insurance in the established market.

\section{ConCLUSION}

Nonprofit organizations, at one time immune from any liability, are now held liable for the torts of their workers, including volunteers, under the doctrine of respondeat superior. Because imposing liability encourages better supervision of volunteers and thus more effective volunteer work, this Comment supports the use of the doctrine of respondeat superior and attempts to dispel any fears that this legal standard will work against volunteerism.

The insurance industry, however, is undermining the beneficial effects of the doctrine of respondeat superior. The insurance problem is grounded in the insurance industry's fears and lack of knowledge about volunteers. The insurers' categorization of most volunteer programs as high-risk, together with the failure to distinguish programs that have developed proper volunteer management, eliminates any incentive for organizations to strengthen control over volunteers. Furthermore, the difficulty of obtaining affordable insurance discourages the use of volunteers.

The proposed statutory scheme seeks to remedy the insurance problem by supporting preferential insurance treatment for those organizations that have significant control over their volunteers and by suggesting rational guidelines to use in determining which organizations in fact exercise this control. In addition to estimating insurance risks more accurately, these guidelines could be used by organizations to improve the quality of volunteer work. Furthermore, the availability of insurance would encourage organizations to expand the volunteer's role. Although this proposal may be criticized for giving preferential treatment to volunteer programs, the tremendous value of volunteerism to our society warrants special treatment to ensure the continued safe delivery of volunteer services. 